\title{
City Waste Compost and Sustainability of Rice-Wheat Cropping System
}

\author{
Krishna B. Karki \\ Nepal Agricultural Research Council (NARC), Khumaltar, Nepal, \\ $<$ krishna@drkbk.wlink.com.np>
}

\begin{abstract}
An experiment was conducted on Rhodic Ustochrept soil in Central Hill of Nepal growing wheat-mungbean-rice in rotation. Grain yields as affected by $28 \mathrm{t} \mathrm{ha}^{-1} \mathrm{a}$ of town compost were compared with the same amount of farmyard manure and N:P:K (120:60:40). NPK produced significantly higher wheat grain $\left(3897 \mathrm{t} \mathrm{ha}^{-1}\right)$. Other yield results were at par with one another. NPK produced lowest mungbean yield. After growing second crop fertility seems to be exhausted thus rice yield indicated no notable residual fertilising effect. FYM and town compost left noteworthy amounts of $\mathrm{P}, \mathrm{Ca}, \mathrm{Mg}$ and $\mathrm{K}$ even after rice harvest.
\end{abstract}

Key words: Organic manure, plant nutrients, sustainability

\section{INTRODUCTION}

Population growth and concentration, rising affluence, technological changes, and rising expectation and awareness all lead to higher levels of consumption and waste generation. In Kathmandu valley, 400 $\mathrm{g}$ wastes are produced per person every day of which $80 \%$ is biodegradable. The remaining $20 \%$ includes paper, plastics and other wastes. The present population of the valley produces about 320 tons of waste, which could give 48 tons of compost everyday (Joshi 2000). The end product of the degradable waste (compost) is consumed by agriculture since it contains sufficient amounts of plant nutrients, including most of the micro-elements. If it is properly managed it could be a valuable resource and alternative for the imported and expensive mineral fertilisers. But most of the municipality wastes contain dangerous heavy metals which might find their way into the food chain and pose hazard to human as well as animal. Because of its beneficial effects in supplying plant nutrients, enhancing the cations exchange capacity, improving soil aggregation, water retention and also supporting soil biological activities, organic manure is regarded as most valuable resource in agriculture (Dudal and Deckers 1993). Aapplication of ample amounts of manure leads to soil sustainability (Swift and Woomer 1993). In addition organic soil amendments control some root pathogens (Buruchara 1992). Therefore, compost produced from city waste is potentially very valuable resource in Nepalese agriculture. With the aim of comparing crop yield as affected by these manures and its residual values in succeeding crop a study was conducted in the farmers' field at Kalleritar of Dhadhing district in 1993/1994.

\section{METHODOLOGY}

The study was carried out on a river terrace soil classified as Rhodic Ustochrept (Cambic fluvisol), which was medium in texture, deep and well drained. A field experiment was conducted growing wheat followed by mungbean and rice. The experiment was conducted in a randomized block design (RBD) with farmyard manure (FYM $\left.28 \mathrm{t} \mathrm{ha}^{-1}\right)$, city waste compost $\left(28 \mathrm{t} \mathrm{ha}^{-1}\right)$ and NPK fertilizers (120:60:40) and the results were compared with control. Fertilizers were applied to wheat crop, and mungbean and rice were grown on residual fertilizer leftover by the wheat crop. Mungbean biomass was incorporated 
into the soil after the mungbean pods were harvested and then rice seedlings were planted. The crops were harvested on maturity, cleaned and adjusted with $14 \%$ moisture and then weighed. The yield data were analyzed with MSTATC statistical package with 5\% level of significance. Soil samples before and after the experiments were collected and extracted using acid ammonium acetate + EDTA and organic manure digested in Aqua Regia and measured in inductive plasma photometer (ICP).

\section{RESULTS AND DISCUSSION}

The chemical properties of compost and FYM (decomposed mixture of dung, urine and bedding materials) are presented in Table 1. Both the materials contain sufficient amounts of plant nutrients. FYM contains twice the amount of total nitrogen than that of town compost contains which is a superior fertilizing material than town compost. All nutrients were higher in FYM except calcium.

Table 1. Plant nutrient contents of organic manures as extracted by Aqua Regia

\begin{tabular}{lrr}
\hline Element & Town compost & FYM \\
\hline Total N, \% & 0.445 & 0.965 \\
Organic C, \% & 14.74 & 14.505 \\
Total P, mg kg & 3094.74 & 4235.89 \\
Total K, mg kg & 7866.02 & 17917.91 \\
Magnesium, mg kg & & 9784.70 \\
Calcium, mg kg & 4426.51 & 11370.22 \\
\hline
\end{tabular}

Soil fertility level at the experimental site was low. This resulted in a good response of applied fertilizers. Wheat grain yield with application of NPK fertilizer was $3897 \mathrm{~kg} \mathrm{ha}^{-1}$, which was significantly higher than the result from other treatments (Table 2). It could be because the nutrient elements in the mineral fertilizer were in the readily available form whereas it needs to be mineralized in the case of organic manure. The rate of mineralization during the cold season is slow (Suzuki et al 1990) because in such condition during winter mineralization of mineral nutrients from organic sources is less than $30 \%$ in a year (Takenaka et al 1990). Responses of organic manures were at par with those of control. Ratanapratip et al (1987), Bory and Nemeth (1992) had obtained similar results.

Table 2. Grain yields as affected by fertilizer application

\begin{tabular}{lccc}
\hline \multirow{2}{*}{ Treatment } & \multicolumn{3}{c}{ Grain yield, kg ha ${ }^{-1}$} \\
\cline { 2 - 4 } & Wheat grain yield & Mung bean yield & Rice grain yield \\
\hline Control & $1194 \mathrm{~B}$ & 515 & 1170 \\
FYM & $1477 \mathrm{~B}$ & 481 & 1345 \\
Town compost & $1610 \mathrm{~B}$ & 567 & 1277 \\
NPK & $3897 \mathrm{~A}$ & 426 & 1063 \\
\hline F test & $* *$ & $\mathrm{Ns}$ & $\mathrm{ns}$ \\
CV $\%$ & 8.83 & 16.34 & 12.6 \\
SD & 93.667 & 34.57 & 40.26 \\
\hline
\end{tabular}

Figures indicated by the same alphabets are not significantly different at 5\% level.

Grain yield of mungbean was highest $\left(567 \mathrm{~kg} \mathrm{ha}^{-1}\right)$ as affected by town compost and the lowest value was obtained due to NPK application $\left(426 \mathrm{~kg} \mathrm{ha}^{-1}\right)$. Similar yield results were also obtained in North Indian plains in rice-wheat rotation (Maskina et al 1989).

Rice grain yield was $1345 \mathrm{~kg} \mathrm{ha}^{-1}$ with the application of FYM (Table 2). Soil fertility before the experiment was low and the addition of organic manure and the biomass of mungbean did not add notable amounts of nutrient elements as indicated by rice grain yield which were at par with one another. Depending upon the amount of green manure incorporated into the soil, the use of green manure alone could produce a rice grain equivalent of 60 to $120 \mathrm{~kg} \mathrm{ha}^{-1} \mathrm{~N}$ (Bhopari et al 1992, Maskina 
et al 1989, Kolar, Grewal 1988). In this case mungbean biomass after the harvest of the matured pods did not add sufficient amount of nitrogen in the soil. Nitrogen is one of the most limiting nutrients in the Nepalese soil (Sillanpää 1982).

In this experiment, organic manure exhibited considerable residual value (Table 3). There were positive results from the plots previously treated with the FYM and town compost and a negative response from the NPK treated plots. It could be due to significantly higher yield of wheat due to NPK application and very little fertilizing elements could have been available for the third crop (rice). Therefore, there was no significant difference in the yield response with the application of organic manures and NPK treatments. When applied to each and every crop the effect of applied organic manures could be observed only after two or three years (Sherchan and Chand 1991). Results from long term fertility research showed FYM applied at the rate of $10 \mathrm{t} \mathrm{ha}^{-1}$ year $^{-1}$ yielded almost the same amount of wheat grain as 100:30:0 NPK, which was significantly higher than the production from the application of half the dose of NPK + stubble incorporation (Sherchan and Baniya 1991).

Table 3. Physico-chemical properties of surface soil

\begin{tabular}{lrrrrr}
\hline Properties & Before experiment & \multicolumn{5}{c}{ After experiment } \\
\cline { 3 - 7 } & & Control & FYM & Town compost & NPK \\
\hline PH & 6.75 & 6.98 & 6.87 & 6.98 & 7.01 \\
Total N, \% & 0.065 & nd & nd & nd & nd \\
Organic carbon, \% & 1.2 & nd & nd & nd & nd \\
\hline Acid Ammonium Acetate+ EDTA Extractable plant nutrients $\left(\mathrm{mg} \mathrm{kg}^{-1}\right)$ \\
Ca & 1749.12 & 1545 & 1748.99 & 1900.00 & 1660.15 \\
$\mathrm{Mg}$ & 37.45 & 36.9 & 41.499 & 40.2 & 38.34 \\
$\mathrm{P}$ & 135.96 & 76.93 & 119.97 & 136.01 & 86.75 \\
$\mathrm{~K}$ & 157.12 & 121.64 & 181.79 & 166.47 & 149.38 \\
\hline
\end{tabular}

nd $=$ not detected.

In all the treatments there was slightly increased in soil $\mathrm{pH}$. The rise in $\mathrm{pH}$ might due to flooding showing reduced condition for a long time (Ponnamperuma 1972). In control treatment exchangeable $\mathrm{Ca}$ was much below and all the other treatments exhibited considerable increase and in most of the cases higher than the amount present before experiment. There was considerable amount of available $\mathrm{Mg}$ and $\mathrm{K}$ even after the third harvest. Control treatments showed decrease in the mineral nutrients indicating nutrient mining from the soil (Ghani and Brown 1997, Joshi 1997). Comparing the amount of potassium before and after the experiment in all the treatments organic manure addition gave noteworthy amount but the NPK treatment resulted in lower than the K that has been found before the experiment. The harvested crops had exhausted plant nutrients as indicated by lower $\mathrm{Ca}, \mathrm{Mg}, \mathrm{P}$ and $\mathrm{K}$ values in control plots than the values before the experiment. There was heavy mining of $\mathrm{K}$ from soil and replenishment through fertilizer and organic manure being was not enough to satisfy the harvested K. This decreases $\mathrm{K}$ reserve in soil. If this condition continues in intensively cultivated fields $\mathrm{K}$ reserve will be exhausted and no crop yield can be obtained from soil (Karki 2004). Similar effects were also produced in the NPK treated plots. Obviously the town compost and FYM treated plots added notable amounts of these elements (Table 3). Similar results have been reported by Bhandari et al (2002), Ladha et al (2000).

\section{Sustainability of rice -wheat system}

Most of the authors dealing with sustainable agriculture like Swift and Woomer (1993), Dudal and Deckers (1993), Bauer and Black (1994) have emphasized on low inputs, and organic farming taking into consideration of the environment and its degradation. In this context use of low input organic farming treatments have been compared to mineral fertilizer and found that the low input agriculture has favorable physical and chemical residual effect on soil and crop production. Comparing the effect of organic manure to that of control and chemical fertilizer on grain yield the result of first crop is obviously highest, due to application of mineral fertilizer but its residual effect decreased after second and the third crop. It is evident from these results that the application of mineral fertilizer especially $\mathrm{N}$ 
could produce sustainable crop yields if it could be used for every crop but not only once a year. Nevertheless, the residual effect of the applied $\mathrm{P}$ and $\mathrm{K}$ fertilizer is worth mentioning. Even after removal of these elements by three harvests there were sufficient for a fourth crop. These results show that the organic manure had positive results in maintaining soil quality and hence sustainability.

\section{CONCLUSION}

Although the amount of plant nutrients in town compost is comparatively low, yet the crop yield is not inferior to that with FYM application. Application of NPK on the other hand yielded significantly higher only in the case of wheat. Residual plant nutrient contents in the soil after the crop harvest were found higher where town compost and FYM was applied. It could thus be concluded that organic manure has valuable effects on the chemical properties of soil.

\section{ACKNOWLEDGEMENT}

Funding for this study was provided by Solid Waste Management and Resources Mobilization Centre, Kathmandu and is thankfully acknowledged.

\section{REFERENCES}

Bauer A and AL Black. 1994. Quantification of the effect of soil organic matter content on soil productivity. Soil Sci. Soc. Am. J. 58:185-193.

Bhandari AL, JK Ladha, H Pathak, AT Padre, D Dawe and RK Gupta. 2002. Yield and soil nutrient changes in a long-term rice-wheat rotation in India. Soil Science Society of America Journal 66:162-170.

Bhopari BS, Y Singh and BD Sharma. 1992. Effect of green manuring with susbenia aculata on physical properties of soil and growth of wheat in rice-wheat and maize-wheat cropping system in a semiarid region of India. Arid Soil Research and Rehabilitation 5:135-143.

Bory EL and I Nemeth. 1992. Effect of organic and inorganic nutrients forms on leaf cover, dry matter accumulation and yield of wheat. Novenytermeles (Hungary) 41:337-350.

Buruchara RA. 1992. Use of soil amendment in the management of beans. In: Proc. Seminar on Bean Breading in the Great Lake. CIAT, Cali. Columbia.

Dudal R.and J Deckers. 1993. Soil Organic matter in relation to soil productivity. In: Soil Organic Matter Dynamics and Sustainability of Tropical Agriculture (K Mulongoy and R Merec, eds). 377-380.

Ghani A and MW Brown. 1997. Improvement of soil fertility in Nepal through balanced application of fertilizers. Report submitted to Ministry of Foreign Affairs and Trade, Wellington.

Joshi D. 1997. Soil fertility and fertilizer use in Nepal. Soil Science Division, Khumaltar, Lalitpur, Nepal. Pp. 70.

Joshi PS. 2000. Role of municipality in food security. In: Proc. International Conference and Workshop: Food Security of Urban and Peri-urban System in Developing Countries, Vienna, 15-18 November 2000. Pp. 2528.

Karki KB. 2004. Status of potassium in intensively cultivated soils of Kathmandu valley. Nepal Journal of Science and technology 5:83-89.

Kolar JS and HS Grewal. 1988. Green manure to sustain productivity and save nitrogen for Rice-wheat cropping systems. IRRI Newsletter 13:29.

Ladha JK, KS Fischer, M Hossain, PR Hobbs and B Hardy. 2000. Improving the productivity and sustainability of rice-wheat systems of the Indo-Gangetic Plains: A synthesis of NARS-IRRI partnership research. Disc. Paper no. 40. International Rice Research Institute, Philippines.

Maskina MS, B Singh, OP Meelu, B Singh and Y Singh. 1989. Integrated N Management with green manures in rice-wheat rotation. IRRI Newsletter 12:38-39.

Ponnamperuma FN. 1972. Chemistry of submerged soil. Adv. Agron. 24:29-91.

Ratanapratip P, T Suwanawet and W Kongpolprom. 1987. Effect of soil improvements and chemical fertilizers on wheat yield. In: Proceedings Wheat Research and Development Workshop 1987/88. Pp. 364-378.

Sherchan DP and SP Chand. 1991. A review of current soil related research activities at Pakhribas Regional Agricultural Centre. In: Workshop Proceedings, Jhikhu Khola Watershed, 22-25 April, ISS/IDRC/UBC Canada. Pp. 83-104. 
Sherchan KK and BK Baniya. 1991. Crop production trend in response to soil and nutrients: Soil Fertility and erosion issues in the Middle Mountain Region of Nepal. In: Workshop Proceedings, Jhikhu Khola Watershed, 22-25 April, ISS/IDRC/University of British Columbia, Vancouver, Canada. Pp. 51-60.

Sillanpää, 1982. Micronutrients and nutrients status of soil: A global study. FAO Soil Bulletin No. 48:242-250.

Suzuki MRS, K Kamekawa, S Sekia and H Shiga. 1990. Effect of continuous application of organic fertilizer for sixty years on soil fertility and rice yield in paddy field. Trabsaction XIV International Congress of Soil Science. Pp. 14-19.

Swift MJ and PL Woomer. 1993. Organic matter and sustainability of agricultural system: Definition and measurement. In: Soil Organic Matter Dynamics and Sustainability of Tropical Agriculture (K Mulongoy and R Merec, eds). Pp. 3-18.

Takenaka M, T Miyoshi, K Hori and T Matsuguchi. 1990. Effect of soil temperature on nitrogen mineralization of different soil types of winter wheat fields. Transaction XIV International Congress of Soil Science IV:587588. 